\title{
Gender Dimensions in Fuel Wood Management: Some Implications for Adoption of Cleaner Energy Source in Kano Region
}

\author{
Nuratu Mohammed Phd And Mairo Haruna \\ Department Of Geography, Bayero University, Kano
}

\begin{abstract}
This study examines gender dimension in fuel wood management in some rural areas of Kano and Jigawa States. Data was collected using the Focus Group Discussion technique (FGD) with a total sample of 63 women and nine (9) men from nine ( 9 ) settlements in Kano and Jigawa states. Research findings showed that majority $(97 \%)$ of the women in the settlements have preference for the use of biomass energy types especially fuel wood for cooking. Since majority use fuel wood, it was found that $98 \%$ use the three hearth stone technology. As far as the household management of fuel wood is concerned the men are responsible for sourcing and procurement as well as processing while the women are responsible for storing and usage. A greater percentage of the women (63\%) are aware of other energy sources but the decision to use what type of energy resides with the men as they are the providers for their family. Some of the reasons for the non adoption of other energy types from the perspectives of women are: affordability and efficiency especially bearing in mind the socio economic status of most rural households and the extended nature of most rural families/ size of rural households in question. It is recommended that in view of the rapid depletion of environmental resources which have been attributed to the overexploitation of the forests resources, there is the need to harness and subsidize alternative /clean energy sources. And women being the end users of energy should be involved in decisions that pertain the introduction of alternative clean energy sources through consultations and enlightenment via seminars, focus discussions media awareness campaign and they need to be empowered on the type of energy to be used.
\end{abstract}

Keywords: Fuel wood, energy, gender, rural and management

\section{INTRODUCTION}

Energy is one of the basic requirements of human societies and a key input to economic and social development (UNDP, 2003; Olatinwo, 2012; Ojo et al 2013). Energy and fuel use are important for the welfare of households in developing countries. Using an energy source for lighting and cooking is essential to human life and technological advancement. In general, energy can contribute to the widening of opportunities and empower people to exercise choices( Kobede et al ,2010).

To this day, many people remain dependent on traditional biomass fuels for cooking and on inefficient and costly sources of light such as candles and kerosene. Improving access to modern energy sources electricity for light and appliances and clean cooking technologies - is an important development goal; it is complementary with other goals of development such as improving health and education (Babanyara et al 2010). Clean cooking fuels are important for combating the high levels of indoor air pollution encountered whenever traditional solid fuels are used for cooking or heating. The use of clean cooking fuels can also have positive effects on the external environment by reducing outdoor air pollution from venting of kitchen smoke as well as by combating forest degradation; collection of wood for firewood or charcoal production is thought to contribute to forest degradation in certain locations, especially near cities and major roads (Cline Cole et al 1987; Maconachie et al 2008; Friends of the environment, 2005; Bolaji, 2012). Modern fuel and energy use can improve productivity in numerous ways, for example by re-directing scarce labor, biomass and land resources away from fuel collection and production towards agricultural and other uses.

Confirming this assertion Olatinwo et'al (2012), opine that developing countries in particular need to expand access to reliable and modern energy services if they are to reduce poverty and improve the health of their citizens, while at the same time increasing productivity, enhancing competitiveness and promoting economic growth and sustainable development.( Openshaw 2010; Ojo et al,2012;Nnaji et al 2012; Eleri 2012).

Despite the fact that Nigeria is an energy resource country blessed with fossil resources such as crude oil, natural gas, coal and renewable energy resources like solar, wind, and biogas however the use of solid biomass such as firewood is prevalent and constitutes a major energy sources for most rural dwellers in Nigeria. Unfortunately, it's continuous usage leads to environmental degradation (Bolaji et al 2012). 
As a result of this, policy interventions targeting cooking fuels and cooking practices were earlier mostly motivated from a desire to control deforestation; increasingly, such interventions are now being motivated due to concerns regarding indoor air pollution. Indoor air pollution has been estimated by the UNDP (2003) to be the world's 4th largest killer, causing perhaps 2.5 million premature deaths a year. Policies to reduce indoor air pollution focus on either inducing a healthier fuel choice or on making biomass use cleaner and safer, for example through improved stoves or better ventilation in the cooking area (Ezzati et al 2001;Mahat,2006; Obeh 2006).

The role of women in traditional set-up as anchor in the stability of household is well known, their importance in household related matter is paramount. The UNDP (2000) Cecelski (2000); Gbadegesin (2011) and FAO (1987) all opined that energy and women are linked in many diverse ways . These linkages vary spatially, over time, across classes, between rural and urban area and between countries. One of the factors that influence the nature of linkages between energy and women is spending enormous time and effort in gathering energy for the household use. Thus, it is obvious that energy needs at household level are directly related to women's workload and their time as such women are the ones affected most by energy crisis (Dankelman ,2002 ; Ezzati et al 2001;Ojo et al 2013)As a result this, understanding the gender dimensions in household energy becomes The study therefore examines some issues on women and energy and its implication on resource management in parts of Kano and Jigawa states with a view to ascertaining the decision making role of women in energy management for policy making ( Ojo et al 2012).

\section{Definition of Terms}

The term, gender is used to describe all the socially constructed attributes, roles, activities, and responsibilities connected to being a male or a female in a given society(Falola,1996). This means that our gender identity determines how we are perceived, and how we are expected to think and act as women and men, because of the way society is organized. Thus, although the physical differences between the sexes are universal, gender is extremely variable between and within societies. For example, being a woman in one culture carries with it roles and expected behavior very differently from those women in other cultures (Clark,1985) Management, on the other hand, is the skillful control of resources by those who ensure that they are used economically and with forethought (Morse and Clark, 1985). It includes those activities which are designed to govern the use of lands, forests, the atmosphere, waters, and mineral resources in a given environment, taking into account environmental constraints, social, economic, and political implications, technological inventions, national policy, and possible future needs (Clark, 1985).

The term, rural landscape, refers to the countryside and all resources that it possesses and the interrelationships that are established in it (Clock and Park, 1985). It is generally dominated by extensive land uses, such as agriculture and forestry, or large open spaces of underdeveloped land. It also contains small loworder settlements, which demonstrate a strong relationship between buildings and the surrounding extensive landscape of varied phenomena, including grass, animals, soil, rocks, lakes, and the atmosphere. According to Clock and Park (1985), the rural landscape engenders a way of life characterized by a cohesive identity based on respect for the environment and behavioral qualities of living as a part of an extensive (rural) landscape.

\section{MATERIALS AND METHOD}

Data for the research was collected using the Focus Group Discussion with sixty three women and nine men selected from nine settlements in Kano and Jigawa states. A total of 44 households with a population of approximately 450 people formed the sampling frame in the nine (9) study sites where a total of 63 women were involved in the Focus group discussion (FGD) and nine men were interviewed. The opinion of the male head was sought in each compound sampled to confirm some of the information gotten from the women and shade more lights on some issues. The samples selection and size is shown in table 1 Data sourced from respondents include among others, respondents' educational level and major occupation, source and type of energy used in the home, cost and availability of energy sources and knowledge of alternative energy sources and their use or adoption. Collected data was analyzed by descriptive statistical analysis.

Table1: Study Villages and Sample Size

\begin{tabular}{|l|l|l|l|}
\hline $\begin{array}{l}\text { STUDY } \\
\text { VIILAGES }\end{array}$ & $\begin{array}{l}\text { TOTAL } \\
\text { HOUSEHOLDS }\end{array}$ & TOTAL POPULATION & SAMPLES FEMALES \\
\hline Takaratsa & 5 & 40 & 7 \\
\hline Kahotara & 5 & 20 & 5 \\
\hline U/rimi & 2 & 10 & 4 \\
\hline Kwangi & 2 & 18 & 4 \\
\hline S/gari & 3 & 25 & 5 \\
\hline Kiru & 12 & 128 & 16 \\
\hline
\end{tabular}




\begin{tabular}{|l|l|l|l|}
\hline Birni 1 & 6 & 112 & 9 \\
\hline Birni 2 & 5 & 57 & 7 \\
\hline Birni 3 & 4 & 33 & 6 \\
\hline TOTAL & 44 & 443 & 63 \\
\hline
\end{tabular}

Source: Field work, 2014.

Key:

Birni 1: Birniwa 1

Birni 2: Birniwa 2

Birni 3: Birniwa 3

The study cover parts of the larger Kano region (Kano and Jigawa states Fig.1) made up of Kano and Jigawa states where some villages in Tofa, Rimin Gado and Kiru were selected as study sites in Kano state . Tofa is located between longitudes $8^{0} 10^{\prime} \mathrm{E}$ to $8^{0} 30^{\prime} \mathrm{E}$ and latitudes $12^{0} 10^{\prime} \mathrm{N}$ to $11^{0} 50^{\prime} \mathrm{N}$ in the North central Part of Kano State. It is bordered by Ungogo Local Government Area in the East, Kabo Local Government in the north and Kura Local Government in the south East. Specifically the study sites are ,Lambu kahotara,Unguwar Rimi,Kwangi Sabongari in Tofa local government area,Kiru is located on $11^{\circ} 41^{\prime} 59^{\prime \prime}$ and longitude $8^{\circ} 7^{\prime} 57^{\prime \prime}$ Rimin Gado is located on (Takaratsa) and Birniwa is located on latitude $12^{\circ} 47^{\prime} 28^{\prime \prime}$ " and longitude $10^{\circ} 14^{\prime} 05^{\prime \prime}$

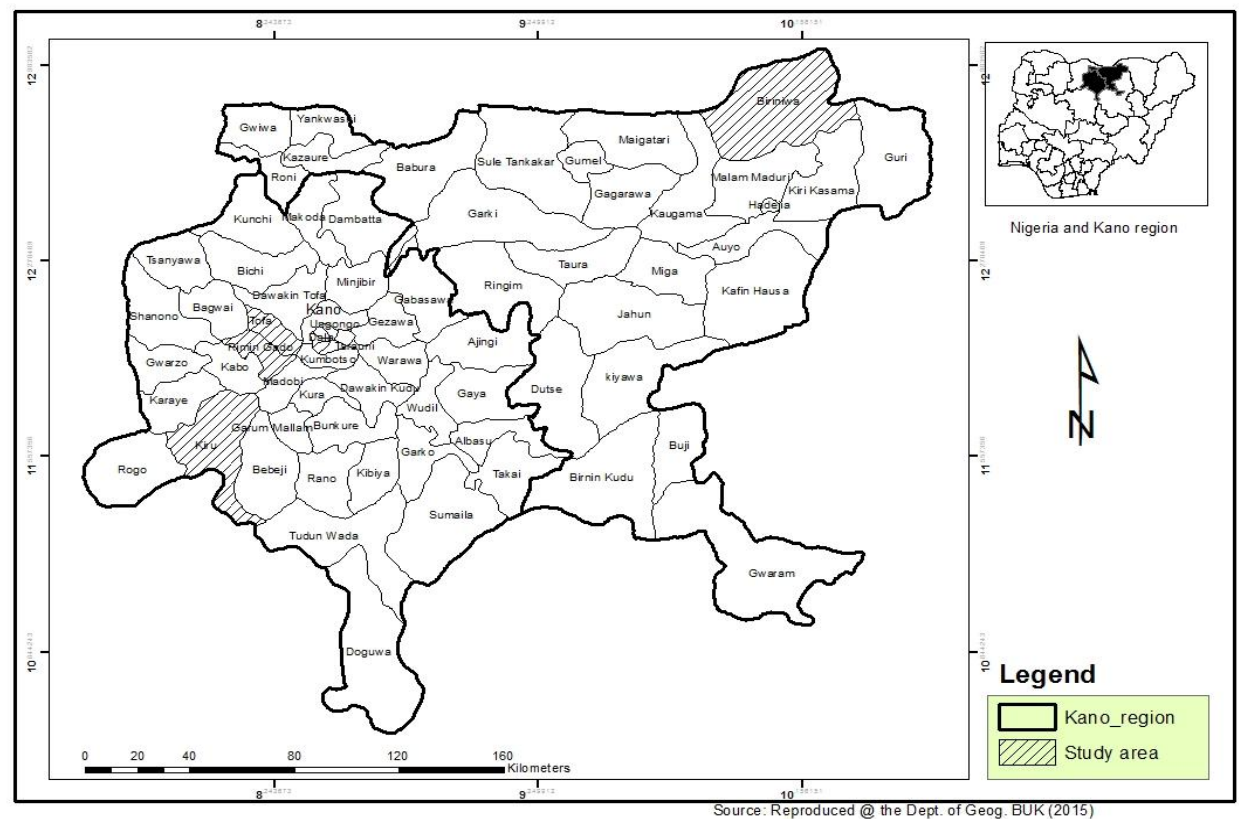

Figure 1: Map of Kano and Jigawa (Kano Region) Showing the Study Areas

The climate of the region is the tropical wet and dry type of climate coded as AW by Koppens classification. Olofin (1987) pointed out that the annual rainfall is received between May and October, with storm and torrential pours in July and August. December record little or no rainfall. The highest amount of rainfall is recorded in August the annual total rainfall is given at about $600 \mathrm{~mm}-700 \mathrm{~mm}$.

The temperature regime is warm to hot through the year, even though there is slightly cool period between November and February. The mean annual temperature is about $26^{\circ} \mathrm{C}$ while the mean monthly value ranges between $21^{\circ} \mathrm{C}$ in the coolest month (December and January), and $31^{\circ} \mathrm{C}$ in the hottest month (April and May) (Olofin,E.A 2014) The natural vegetation of the area is the Sudan and the Sahel Savannah type of vegetation, composed of a variety of trees scattered over grassland and thorny shrubs. Most of the trees are of average height of $3 \mathrm{~m}-15 \mathrm{~m}$, and are characterized with broad canopies and grasses which grow hardly taller than than1.5m.Typical examples of such trees is the Baobao (Adansonia Digitata) which is common all over the landscape others are Africa ebony (Diospros, mosphiliformis) tamarind (Tamarindus indica),Kalgo (Pillostigma tshoning ) (Badamasi M,M 2014) Most of the trees in the area have adapted to the climatic environment by developing long tap roots, leathery leaves and tiny leaves and shedding their leaves during the dry season to check the loss of water through evapo transpiration. 


\section{RESULTS AND DISCUSSION}

The results of the data collected is presented in tables and discussed below. The results of the data collected on the age of women in table 2 revealed that approximately $75 \%$ of the total respondents sampled are less than 30years, slightly less than a quarter $23 \%$ of the sample fell within the age bracket of 40-50years. For the male respondents majority $89 \%$ were within the age bracket of 50years and above, approximately $11 \%$ was within the age bracket of 30-40 years. The implication of this on energy choice cannot be emphasized as the age bracket in which most of the respondents' fall that is the ages 30 years are the active and innovative and productive years in the life of an individual.

Table 2: Age of Respondents

\begin{tabular}{|c|c|c|c|c|c|c|}
\hline \multirow{3}{*}{$\begin{array}{l}\text { STUDY } \\
\text { VIILAGES }\end{array}$} & \multicolumn{6}{|c|}{ AGE OF RESPONDENTS } \\
\hline & \multicolumn{2}{|c|}{ Below 30} & \multicolumn{2}{|c|}{$30-40$} & \multicolumn{2}{|c|}{50 and above } \\
\hline & $\mathbf{F}$ & & $\mathbf{F}$ & $\mathbf{M}$ & $\mathbf{F}$ & I \\
\hline Takaratsa & 4 & 0 & 2 & 0 & 1 & 1 \\
\hline Kahotara & 4 & 0 & 1 & 0 & 0 & 1 \\
\hline U/rimi & 3 & 0 & 1 & 0 & 0 & 1 \\
\hline Kwangi & 3 & 0 & 1 & 0 & 0 & 1 \\
\hline S/gari & 4 & 0 & 1 & 0 & 0 & 1 \\
\hline Kiru & 13 & 0 & 3 & 1 & 0 & 0 \\
\hline Birni 1 & 7 & 0 & 2 & 0 & 0 & 1 \\
\hline Birni 2 & 5 & 0 & 2 & 0 & 0 & 1 \\
\hline Birni 3 & 4 & 0 & 2 & 0 & 0 & 1 \\
\hline TOTAL & & 0 & 15 & 1 & 1 & 8 \\
\hline
\end{tabular}

Source Field work, 2014

The inference drawn from table 3 is that majority of the respondents (84\%) had Quranic education while just about $16 \%$ had some form of Western education. Almost all the males (89\%) in the study settlement had quranic education. The implication of the level of education on the adoption of new technologies including that of improved energy saving stoves cannot be overemphasized. Education it should be pointed out has a bearing on the adoption of innovation also has implication for attitude change. This is reflected in the respondent's attitudes to adopt the new energy types and cooking appliances. The focus group discussion held with the females in the villages revealed that those that were found to be using energy saving stoves are aware and have one form of western education or the other.

Table 3: Respondents Education level

\begin{tabular}{|c|c|c|c|c|c|c|}
\hline \multirow{4}{*}{$\begin{array}{l}\text { STUDY } \\
\text { VIILAGES }\end{array}$} & \multicolumn{6}{|c|}{ EDUCATION OF RESPONDENTS } \\
\hline & \multicolumn{2}{|c|}{ PRIMARY } & & \multicolumn{2}{|c|}{ QURANIC } \\
\hline & \multirow[t]{2}{*}{$\mathbf{F}$} & \multirow[t]{2}{*}{ M } & & & & \multirow[t]{2}{*}{$\mathbf{M}$} \\
\hline & & & \multicolumn{2}{|c|}{$\begin{array}{l}\text { SECONDARY } \\
\mathrm{F}\end{array}$} & & \\
\hline Takaratsa & 0 & 0 & 0 & 0 & 7 & 1 \\
\hline Kahotara & 0 & 0 & 1 & 0 & 4 & 1 \\
\hline U/rimi & 0 & 0 & 0 & 0 & 4 & 1 \\
\hline Kwangi & 0 & 0 & 1 & 0 & 3 & 1 \\
\hline S/gari & 0 & 0 & 1 & 0 & 4 & 1 \\
\hline Kiru & 0 & 0 & 3 & 1 & 13 & 0 \\
\hline Birni 1 & 0 & 0 & 2 & 0 & 7 & 1 \\
\hline Birni 2 & 0 & 0 & 1 & 0 & 6 & 1 \\
\hline Birni 3 & 0 & 0 & 1 & 0 & 5 & 1 \\
\hline TOTAL & 0 & 0 & 10 & 1 & 53 & 8 \\
\hline
\end{tabular}

Source: Field work, 2014

The results in table 4 show that majority of the household head had more than one income source in addition to farming the house head at Kiru for instance was a civil servant and the district head. Other heads in addition to farming do other secondary occupation as butchering, shoe cobblers, sales of grains, petty trading of commodities. As far as the women are concerned, majority of them $(41 \%)$ are into petty trading followed by those processing agricultural products such as groundnut oil and locust bean production and sale of cooked food $(33.33 \%)$ while $(22.22 \%)$ of the women in all the study sites are into handcraft (tailoring, weaving and knitting). Those in farming and civil service have the least number $2 \%$ in each category. The predominance of women in 
the informal sector of the economy has its roots in the form of education they have received as shown in table 3 . Majority had no formal education which could have qualified them into the formal labor force market. Most of the occupation carried out by the women operates within the home environment in conformity with the culture of the settlements. And as for the processing of agricultural products and sale of cooked food the women claim that they use their own personal money to buy the fuel wood they use for their own business.

Table 4

\begin{tabular}{|c|c|c|c|c|c|c|c|c|c|c|c|c|}
\hline \multirow{3}{*}{ VILLAGES } & \multicolumn{12}{|c|}{ OCCUPATION } \\
\hline & \multicolumn{2}{|c|}{ Farmin } & \multicolumn{2}{|c|}{ Processing } & \multicolumn{2}{|c|}{ Tradin } & \multicolumn{2}{|c|}{ Handcraft } & \multicolumn{2}{|c|}{$\mathrm{C} /$ servant } & \multicolumn{2}{|c|}{ Total } \\
\hline & $\mathrm{F}$ & & $\mathrm{F}$ & & & & $\mathrm{F}$ & & $\mathrm{F}$ & 4 & & M \\
\hline Takaratsa & 0 & $1 *$ & 4 & 0 & 3 & 0 & 0 & 0 & 0 & 0 & 7 & $1 *$ \\
\hline Kahotar & 0 & $1 *$ & 3 & 0 & 1 & 0 & 1 & 0 & 0 & 0 & 5 & $1 *$ \\
\hline U/Rimi & 0 & $1 *$ & 0 & 0 & 3 & 0 & 1 & 0 & 0 & 0 & 4 & $1 *$ \\
\hline Kwangi & 1 & $1 *$ & 1 & 0 & 1 & 0 & 1 & 0 & 0 & 0 & 4 & $1 *$ \\
\hline S/Gari & 0 & $1 *$ & 2 & 0 & 2 & 0 & 1 & 0 & 0 & 0 & 5 & $1 *$ \\
\hline Kiru & 0 & $1 *$ & 8 & 0 & 6 & 0 & 2 & 0 & 0 & 0 & 16 & $1 *$ \\
\hline Birniwa 1 & 0 & $1 *$ & 0 & 0 & 4 & 0 & 4 & 0 & 1 & 0 & 9 & $1 *$ \\
\hline Birniwa 2 & 0 & $1 *$ & 1 & 0 & 3 & 0 & 3 & 0 & 0 & 0 & 7 & $1 *$ \\
\hline Birniwa 3 & 0 & $1 *$ & 2 & 0 & 3 & 0 & 1 & 0 & 0 & 0 & 6 & $1 *$ \\
\hline Total & 1 & 9 & 21 & 0 & 26 & 0 & 14 & 0 & 1 & 0 & 63 & $9 *$ \\
\hline
\end{tabular}

Source: Field work, 2014

: Respondent's occupation

Key-P/ A products=processing of agricultural products

$*=$ Existence of more than one activity

Majority of the respondents (97\%) in all the study settlements use biomass related energy types especially fuel wood. In addition to the use of fuel wood, some women especially those living in settlements close to the urban centers have and use one form of alternative energy type. $3 \%$ of the respondents in all the study settlements use kerosene stove.

The respondents rely on the use of biomass related energy types because they are readily available in the environment in addition to other factors. Table 4 shows the reasons for much reliance on the use of biomass related energy sources. Approximately $43 \%$ in all the study settlements agreed that fuel wood is readily available and $29 \%$ said it is easy to use and more combustible. $16 \%$ of the women said it is affordable and about $6 \%$ of the women agreed that fuel wood is fast and efficient especially considering the size of household in the villages while $5 \%$ of the women agreed that fuel wood has all the advantages identified as a reason of its preference over other types of energy sources. Almost all respondents also agreed that food cooked with fuel wood tasted much better than when cooked on stove. This finding corroborates the submission by Inayatullah (2011) and Hassan et al (2013) which confirmed that rural women energy consumption pattern in most developing countries are characterized by a high dependence on biomass resources, with cooking as the primary end-use. Given that these subsidized stove programs have had limited overall success, a question that then naturally occurs is what will drive a change in the fuels that poor households consume. Majority of the male respondents $100 \%$ were of the view that a change is only possible if giant stoves and kerosene would be subsidized to customers. According to one of the male respondents "We have to provide food shelter and clothing to our family with our meager resources in the face of hard times in Nigeria, kerosene is beyond our reach we have use what is readily available and affordable for us" Thus the inference drawn from the responses of the male respondents their providing their spouses with fuel wood as their energy should be viewed from the perspectives of affordability and availability.

Table 4: Reasons for Preference for fuel wood over cleaner energy

\begin{tabular}{|l|l|l|l|l|l|l|}
\hline \multirow{2}{*}{ Villages } & \multicolumn{5}{|c|}{ Reasons for the choice fuel wood as the main energy type used } \\
\cline { 2 - 7 } & Affordability & Availability & Flexibility & Efficiency & Personality & Total \\
\hline Takaratsa & 2 & 2 & 1 & 2 & 0 & 7 \\
\hline Kahotar & 1 & 2 & 1 & 1 & 0 & 5 \\
\hline U/Rimi & 1 & 2 & 0 & 1 & 0 & 4 \\
\hline Kwangi & 1 & 1 & 1 & 1 & 0 & 4 \\
\hline S/Gari & 2 & 0 & 2 & 1 & 0 & 5 \\
\hline Kiru & 2 & 8 & 6 & 0 & 0 & 16 \\
\hline Birniwa 1 & 3 & 0 & 3 & 3 & 0 & 9 \\
\hline
\end{tabular}


Gender Dimensions in Fuel Wood Management: Some Implications for Adoption of Cleaner Energy..

\begin{tabular}{|c|l|l|l|l|l|l|}
\hline Birniwa 2 & 1 & 3 & 3 & 0 & 0 & 7 \\
\hline Birniwa3 & 0 & 4 & 1 & 1 & 0 & 6 \\
\hline Total & 13 & 22 & 18 & 10 & 0 & 63 \\
\hline
\end{tabular}

Source: Field work, 2014

It has been established that the spouse in the study areas are responsible for v providing the fuel wood used by the women (Field work, 2014). The spouses were asked the sources of biomass they provided. The source of the fuel wood is given in table 5 and it shows that fuel wood used is sourced from the farms. $37 \%$ of the respondents said the fuel wood they use is sourced from their spouses farms, $19 \%$ said they got their wood from the forests, while $44 \%$ said their spouses normally purchase the fuel wood used for cooking and heating. It was found that majority of those who purchase fuel wood are those residing in settlements closer to urban areas where much of the farms and forests have been converted to other urban land uses.

Table 5: Sources of fuel wood used by women

Source: Field work, 2014

\begin{tabular}{|l|l|l|l|l|}
\hline & \multicolumn{4}{|c|}{ Sources of Fuel wood } \\
\hline Villages & Farms & Bush & Market & Total \\
\hline Takaratsa & 6 & 0 & 1 & 7 \\
\hline Kahotar & 3 & 1 & 1 & 5 \\
\hline U/Rimi & 2 & 1 & 1 & 4 \\
\hline Kwangi & 2 & 1 & 1 & 4 \\
\hline S/Gari & 2 & 1 & 2 & 5 \\
\hline Kiru & 2 & 3 & 11 & 16 \\
\hline Birniwa 1 & 3 & 2 & 4 & 9 \\
\hline Birniwa 2 & 1 & 3 & 3 & 7 \\
\hline Birniwa3 & 1 & 4 & 1 & 6 \\
\hline Total & 21 & 15 & 24 & 63 \\
\hline
\end{tabular}

Women being the end users have indigenous knowledge of tree species, the result of the focus group discussion held with the women show that majority $100 \%$ preferred the use of Marke :(Anogeissus shimperii) except of course that it is more expensive and not common like the other species like the Darbejiya (Azadirachta Indica. It was found that few of the women (7\%) preferred to use the Aduwa (Balanite Aegytiaca) and Gawo (Faidherbia Albida) trees. The preference for Marke according to the women is borne out of the fact that it is more combustible and easier to use even during the rainy season when the use of firewood always prove difficult.

As earlier pointed out in this write up, majority of the women in the study areas make use of biomass related energy source for cooking and heating and given the fact the majority of the women are yet to adopt the use of modern and cleaner type of fuels with its characteristic appliances, it then follows that the appliances used in cooking and heating must have to conform to the traditional technologies. Majority of the women (98\%) use the three hearth stone type technology and only $2 \%$ of them make use of the kerosene stove. Some of the reasons advanced for this by majority $100 \%$ of the women is that the three stone hearth allows them to use long branches of trees and unsplit woods conveniently This result is similar to the finding of Cline-Cole et al (1987) which said that women in northern Nigeria use the three-hearth stone because it allows them to use tree branches and unsplit woods. It is also easily accessible as there is no cost incurred in obtaining it. As far as the management of fuel wood in the study settlements is concerned it was found that the men are generally responsible for procurement, processing (including cutting, chopping and pruning of fuel wood). Together with men, women also share in the responsibility of storage in addition to use. As for the storage roles fuel wood brought by the men are usually stored at the entrance of the house (soron gida). Women are responsible for the use of fuel wood which is used for cooking and heating. Some of the reasons advanced by women as to be their problem in using biomass related energy types has to do with the increasing cost over the years The women were asked the cost of fuel wood used daily in an average size household the response is shown in Table 7.

Table 7: Expenditure on wood used.

\begin{tabular}{|c|c|c|c|}
\hline Family size & Less than $¥ 100$ & $\$ 100-\$ 200$ & Over $\$ 200$ \\
\hline Less than 10 & 10 & 10 & 8 \\
\hline 10-20members & 5 & 10 & 7 \\
\hline Over 20members & 10 & 2 & 1 \\
\hline Total & 25 & 22 & 16 \\
\hline
\end{tabular}

Computed from Data, 2014 
Further clarification obtained from the discussion held with the women show that on a general note the fewer the household members the less money spent on fuel wood and those settlements in the rural area that are still able to source their supply of fuel wood from farms and forests spend less on procurement of fuel wood.

\section{CONCLUSION}

In conclusion it can be said that as far as gender dimensions in the management of fuel wood is concerned, the men procures, process and store while women also store and manage the use fuel wood for cooking and heating. Although women are the end users of energy, they are never consulted by policy makers discussions related to the design of technologies on alternative energy appliances and cleaner energy programmes meant for them. Even when they are consulted the problem of who provide what also places a limit to the choice that a woman can make as far as energy type she can use is concerned. For the males who are the providers it can be concluded that increasing costs of living and inadequacy of supply of the cleaner energy types are some of the constraint for switch over to the cleaner energy sources

\section{REFERENCES}

[1]. Babanyara, Y.Y. and Saleh U.F., (2010). Urbanisation and the Choice of Fuel Wood as a Source of Energy in Nigeria. J. of Hum. Ecol., 31(1): 19-26 (2010).

[2]. Badamasi,M.M.(2014) : Vegetation and Forestry ; In A.I.Tanko and S.B.Momale (Eds) Kano :Environment,Society and Development,London and Abuja,Adonisand Abbey Publishers.

[3]. Baiyeganhu, L.J.S and Hassan, M.B.(2014): Rural Household Fuel Transition: Evidence From Giwa Local Government Area, Kaduna State. International Energy Initiative, Elsevier Inc.

[4]. Bolaji, B.O. (2012). Effects of Unsustainable Use of Biomass Energy for Cooking and Strategies for their Reduction in Developing Countries. Dev. Country St.2(3): 19-25

[5]. Clark, A.N. (1985). Dictionary of Geography. Human and Physical Geography Terms Explained. London: Longman

[6]. Cecelski, E.(1995) 'from Rio to Beijing: Engendering the Energy Debate', Energy Policy, Vol.23. UK

[7]. Cecelski, E. (2000) The Role of women in Sustainable Energy Development, National Renewable Energy Laboratory (NREL), Bolder Colorado, U.S.A

[8]. Cline-Cole, R.A., Falola , J.A., Main, H.A.C, Mortimer, M.J., Nichol, J.E. and O' Reilly, F.D. (1990) Wood-fuel in Kano. Report by the rural Energy Research project, Bayero University, Kano to the United Nation University, Development studies Division.

[9]. Cloke, P.J. \& Park, C.C. (1985). Rural Resource Management. London: Croom Helm

[10]. Dankelman, I. (2002). Gender, Environment and Sustainable Development: Understanding Linkages. In Cummings, S.,

[11]. Ezzatti, M and Kannem,D.M.(2001): Indoor Air Pollution from Biomass Combustion and Acute Respiratory Infections in Kenya:An Exposure -Response Study : The Lancet 358(9282);619-24

[12]. FAO (1987) Restoring the Balance women and Forest Resources. Food and Agricultural Organization of the United Nations, Rome.

[13]. Gbadegesin, A. and Olorunfemi F., (2011). Socio-Economic Aspects of Fuel Wood Business in the Forest and Savanna Zones of Nigeria: Implications for Forest Sustainability and Adaptation to Climate Change. Global J.of Hum. Soc. Sci., 11 (1): $45-56$ (2011).

[14]. Hassan M.K, Halder, P., Pelkonen ,P ., and Pappinon,A.(2013): Rural Households' Preference and Attitudes towards Biomass Fuels. Results from Comprehensive Field Survey in Bangladesh accessed through http:www.energysustainsoc.com/content/3/1/24

[15]. Inayatullah,J.,Khan,Hand Hayat,S.(2011) :Determinants of Rural Household Energy Choices :An example from Pakistan.Pol Journal of Environmental Studies 21 (30):635

[16]. Kebede, E.,Kagochi,J.,and Jolly,C.M (2010): Energy Consumption and Economic Development in Sub Saharan Africa. Energy economics Volume 32 Issue 3,May 2010

[17]. Mahat,I. (2006) Gender and Rural Energy technologies': Empowerment perspective. A case study of Nepal, Canadaian Journal of Development Studies, Vol.xxxvii No. 4

[18]. Morse, S. \& Stocking, M. (1995). People and Environment. London: University College Press

[19]. NPC (2006) National Population Census Figures Nigeria. National. Population Commission

[20]. National Bureau of Statistics (NBS) (2006). Official Gazette (FGP 71/52007/2,500 (OL24): Legal Notice on Publication of the Details of the Breakdown of the National and State Provisional Totals, 2006 Census. www.nigerianstat.gov.ng (accessed 28 October, 2011).

[21]. Nnaji C.E; Ukwueze E.R, and Chukwu J.O., (2012a). Determinants of Household Energy Choices for Cooking in Rural Areas: Evidence from Enugu State, Nigeria. Continental J. of Soc. Sci. 5 (2): 1 - 11 (2012).

[22]. Nnaji C.E; Uzoma C.C., and Chukwu J.O., (2012b). Analysis of Factors determining Fuelwood Use for Cooking by Rural Households in Nsukka Area of Enugu State, Nigeria. Continental J. of Environ. Sci. 6 (2): 1 - 6 (2012).

[23]. Ojo, O.S.; Okonkwo M.C.,; Oladele O.N.,; Jayeoba W.A.,; Suleiman R.A., and Yakubu M., (2012). Evaluation of Wood Fuel Exploitation and its Relative Consumption Pattern in Kaduna Metropolis. J. of Edu. and Soc. Res.2 (7): 134 - 143(2012)

[24]. Ojo ,C.O.,Bawa,D.B and Chuffor,L .(2013): Effect of Women's socioeconomic characteristics on household fuel consumption in Damboa local Government Area of Borno State ,Nigeria .Humanities and Social sciences journal,ISSN 2222-1719(paper) issn 2222 -2863 (online) Vol .3,No 1,2013

[25]. Olatinwo, K.B. and Adewumi M.O., (2012). Energy Consumption of Rural Farming Hou seholds in Kwara State, Nigeria. J. of Sus. Devt. in Africa . 14 (2): 63 - 76(2012).

[26]. Onoja, A.O. and Idoko O., (2012). Econometric Analysis of Factors influencingFuelwood Demand in Rural and Peri- Urban Farm Households of Kogi State. The J. of Sus. Devt. 8 (1): 115-127 (2012).

[27]. Onoja, A.O. and Emodi A.I., (2012). Economic Analysis of Fuelwood Production and Consumption: Evidence from a Nigerian State. British J. of Mgt. and Econs 2(1): 13-23

[28]. Oyekale, A.S.; Dare A. M. and Olugbire O. O. (2012). Assessment of Rural Households' Cooking Energy Choice during Kerosene Subsidy in Nigeria: A Case Study of Oluyole Local Government Area of Oyo State. Afr. J. of Agr. Res. 7(39): 5405 - 5411 (2012).

[29]. Obeh, J (2006). Methanol stoves for indoor air Pollution reduction in Delta State Nigeria. Boiling point No. 43

[30]. Olofin, E.A.(1987) Some Aspects of the physical Geography of Kano Region and Related Human Responses Departmental Lecture Note Series No. 1, Department of Geography Bayero University Kano 
Gender Dimensions in Fuel Wood Management: Some Implications for Adoption of Cleaner Energy..

[31]. Openshaw, K. (2010): Biomass Energy: Employment Generation and its contribution to poverty Alleviation. Biomass and Bioenergy 34,pp.365-378

[32]. UNDP (2000). World Energy Assessment. Energy and Challenge of sustainability. United Nations Development Programme, New York

[33]. UNDP (2003) Gender and Energy: how is gender relevant to Sustainable energy policies, in sustainable energy strategies: materials for decision makers, United Nation's Development Programme. 